\title{
Burn wood influence on outdoor air quality in a small village: Foros de Arrão, Portugal
}

\author{
N. Canha $\cdot$ M. C. Freitas $\cdot$ M. Almeida-Silva $\cdot$ S. M. Almeida $\cdot$ H. M. Dung $\cdot$ \\ I. Dionísio - J. Cardoso • C. A. Pio - A. Caseiro - T. G. Verburg • \\ H. Th. Wolterbeek
}

Received: 3 June 2011/Published online: 26 June 2011

(C) Akadémiai Kiadó, Budapest, Hungary 2011

\begin{abstract}
One Plus Sequential Air Sampler-Partisol was placed in a small village (Foros de Arrão) in central Portugal to collect $\mathrm{PM}_{10}$ (particles with an aerodynamic diameter below $10 \mu \mathrm{m}$ ), during the winter period for 3 months (December 2009-March 2010). Particles masses were gravimetrically determined and the filters were analyzed by instrumental neutron activation analysis to assess their chemical composition. The water-soluble ion compositions of the collected particles were determined by Ionexchange Chromatography. Principal component analysis was applied to the data set of chemical elements and soluble ions to assess the main sources of the air pollutants. The use of both analytical techniques provided information about elemental solubility, such as for potassium, which was important to differentiate sources.
\end{abstract}

Keywords Wood burn · Air quality · Rural area . $\mathrm{PM}_{10}$

N. Canha $\cdot$ M. C. Freitas $(\bowtie) \cdot$ M. Almeida-Silva

S. M. Almeida $\cdot$ H. M. Dung · I. Dionísio

Instituto Tecnológico e Nuclear (ITN), URSN, E.N. 10, 2686-953 Sacavém, Portugal

e-mail: cfreitas@itn.pt

J. Cardoso

University of Cape Verde, Campus do Palmarejo, cp 279,

Praia, Cape Verde

J. Cardoso · C. A. Pio - A. Caseiro

Centre for Environmental and Marine Studies, University

of Aveiro, 3810-193 Aveiro, Portugal

T. G. Verburg · H. Th. Wolterbeek

Department of Radiation, Radionuclides and Reactors, Faculty of Applied Sciences, Delft University of Technology, Mekelweg 15, 2629 JB Delft, The Netherlands

\section{Introduction}

Particulate matter (PM) is an issue of concern due to the correlation between its high concentrations and the health effects on humans. This has become a critical air pollution problem. In fact, among European Union (EU) member states, high levels of PM with aerodynamic diameter lower than $10 \mu \mathrm{m}\left(\mathrm{PM}_{10}\right)$ have been reported, mainly in urban agglomerations where human exposure is also higher [1].

To overcome this problem, EU has been updating its legislation towards the limitation of $\mathrm{PM}_{10}$ levels. EU Directive 2008/50/EC establish a daily limit value of $50 \mu \mathrm{g} \mathrm{m}^{-3}$ of $\mathrm{PM}_{10}$ (not to be exceeded more than 35 times in a year) and an annual average limit value of $40 \mu \mathrm{g} \mathrm{m}^{-3}$ of $\mathrm{PM}_{10}$. However, it has been difficult for most of the EU to comply with these criteria.

Corrective or preventive actions to decrease the $\mathrm{PM}_{10}$ levels are needed but to apply them it is necessary to understand the $\mathrm{PM}_{10}$ sources and which of them are possible to act on.

Wood is commonly used in residential combustion for heating and, in Portugal, it contributes for $18 \%$ of total $\mathrm{PM}_{10}$ emissions. In fact, wood smoke represents $98 \%$ of $\mathrm{PM}_{10}$ residential emissions contribution by fuel type [1].

Emissions from residential wood combustion are influenced by several types of factors, such as the type of wood, the structure of the fireplace or furnace, the air supply, the wetness of the wood and burning habits [2]. Due to all these variables, wood chemical profiles are very specific and diversified.

The main components of smoke particles from biomass burning are the monosaccharide derivatives from the breakdown of cellulose and hemicelluloses (e.g., levoglucosan), followed by ionic species (where potassium is a major constituent of biomass ash) and metals, in low and 
varied concentrations. In fact, trees absorb these elements from water and soil and, since a great variability exists in the trace metals availability in soils from region to region, chemical profiles of burning emissions are very specific to each region. Some studies have already been performed to characterize this $\mathrm{PM}_{10}$ component in Portugal $[1,2]$ concerning the main types of wood used.

This work aims to characterize the burning wood profile in a small village where this type of fuel is greatly used for house heating in the winter months and to understand its contribution to outdoor air quality. Instrumental neutron activation analysis (INAA) is used as an important tool to assess a wide range of elements to achieve a chemical profile of these $\mathrm{PM}_{10}$ emissions, where wood smoke is a fundamental component.

\section{Experimental}

Description of the sampling site and equipment

Figure 1 shows the sampling site location (the village of Foros de Arrão is characterized as a rural area and its coordinates are $39^{\circ} 10^{\prime} 43 \mathrm{~N}, 8^{\circ} 14^{\prime} 29 \mathrm{~W}$ ). The village has about a thousand inhabitants and the main method used for house heating in the colder months of the year (NovemberMarch) is through wood burning, mainly from Quercus suber (cork oak) and Eucalyptus globulus (eucalyptus). The Partisol sequential sampler was placed at the center of the village to collect $\mathrm{PM}_{10}$, near to the primary school where burn wood is used for heating. This school has two slow-combustion stoves and two fireplaces working during the weekdays while classes are in session. The sampling period was from 14 December 2009 to 6 March 2010.

The sampler used Teflon ${ }^{\mathrm{TM}}$ filters with a diameter of $47 \mathrm{~mm}$ to collect particles for periods of $24 \mathrm{~h}$ at an airintake rate of $16.7 \mathrm{~L} \mathrm{~min}^{-1}$. The sampler also kept records

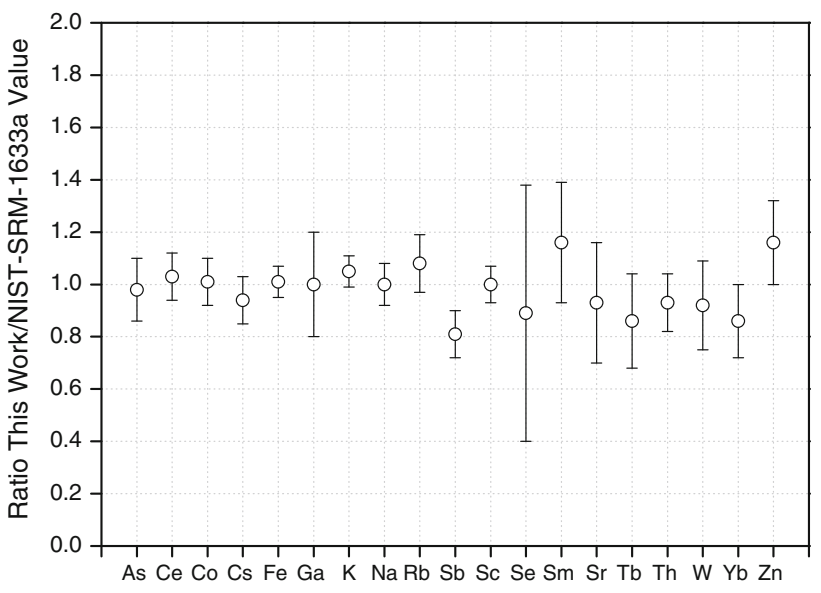

Fig. 2 Ratios between the concentration results obtained in this work for the NIST-SRM-1633a (coal fly ash) and their consensus values [11], with uncertainties at the $95 \%$ confidence level

of air temperature and relative humidity, start and end times of collection, variation in the air flow and the amount of air sampled.

Gravimetric and chemical analysis

The filter loads were determined by gravimetry using a $0.1 \mu \mathrm{g}$-sensitivity balance in a controlled cleanroom (class 10000). The mass of the filter before and after sampling was obtained as the average of three measurements with observed variations of less than $5 \%$.

Each filter was cut into two parts with a ceramic knife inside a Teflon ${ }^{\mathrm{TM}}$ box, without possibility of external contamination. For chemical identification, one half was analyzed by INAA (As, Au, Br, Ca, Ce, Co, Cr, Cs, Fe, Ge, K, $\mathrm{Na}, \mathrm{Rb}, \mathrm{Sb}, \mathrm{Sc}, \mathrm{Se}, \mathrm{Sm}, \mathrm{Th}, \mathrm{W}, \mathrm{Yb}$ and $\mathrm{Zn}$ ) and the other half was analyzed by ion chromatography for the determination of water soluble ions $\left(\mathrm{Cl}^{-}, \mathrm{NO}_{3}^{-}, \mathrm{SO}_{4}{ }^{2-}, \mathrm{Na}^{+}\right.$, $\mathrm{NH}_{4}{ }^{+}, \mathrm{K}^{+}, \mathrm{Mg}^{2+}$ and $\mathrm{Ca}^{2+}$ ).

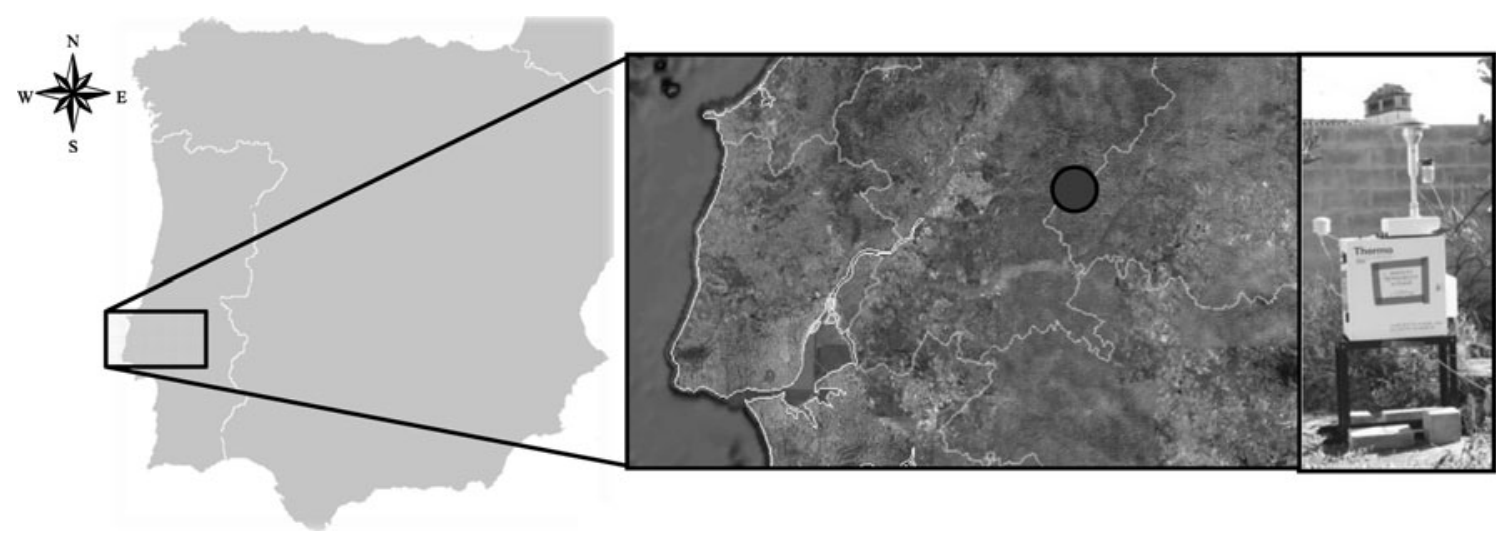

Fig. 1 Outline of mainland Portugal, showing the approximate location of the sampling site described as a rural area 
Table 1 Basic statistics on results of $\mathrm{PM}_{10}$ masses (given by gravimetric method), chemical element concentrations (given by neutron activation analysis), water-soluble ions determination and meteorological parameters

\begin{tabular}{|c|c|c|c|c|c|c|}
\hline Parameter & $\mathrm{N}$ & Minimum & Maximum & Median & Average & SD \\
\hline As $\left(\operatorname{ng~m}^{-3}\right)$ & 36 & $4.89 \mathrm{E}-02$ & $1.24 \mathrm{E}+00$ & $2.02 \mathrm{E}-01$ & $2.79 \mathrm{E}-01$ & $2.29 \mathrm{E}-01$ \\
\hline $\mathrm{Au}\left(\mathrm{ng} \mathrm{m}^{-3}\right)$ & 43 & $5.90 \mathrm{E}-06$ & $5.39 \mathrm{E}-02$ & $1.10 \mathrm{E}-03$ & $3.24 \mathrm{E}-03$ & $8.30 \mathrm{E}-03$ \\
\hline $\mathrm{Br}\left(\mathrm{ng} \mathrm{m}^{-3}\right)$ & 71 & $5.99 \mathrm{E}-01$ & $2.14 \mathrm{E}+01$ & $4.49 \mathrm{E}+00$ & $5.14 \mathrm{E}+00$ & $3.56 \mathrm{E}+00$ \\
\hline $\mathrm{Ca}\left(\mathrm{ng} \mathrm{m}^{-3}\right)$ & 21 & $2.12 \mathrm{E}+02$ & $6.03 \mathrm{E}+03$ & $7.72 \mathrm{E}+02$ & $1.58 \mathrm{E}+03$ & $1.53 \mathrm{E}+03$ \\
\hline $\mathrm{Ce}\left(\mathrm{ng} \mathrm{m}^{-3}\right)$ & 20 & $1.14 \mathrm{E}-01$ & $1.12 \mathrm{E}+00$ & $3.97 \mathrm{E}-01$ & $4.23 \mathrm{E}-01$ & $2.33 \mathrm{E}-01$ \\
\hline $\operatorname{Co}\left(\mathrm{ng} \mathrm{m}^{-3}\right)$ & 22 & $1.28 \mathrm{E}-03$ & $1.04 \mathrm{E}+00$ & $9.51 \mathrm{E}-02$ & $1.98 \mathrm{E}-01$ & $2.66 \mathrm{E}-01$ \\
\hline $\mathrm{Cr}\left(\mathrm{ng} \mathrm{m}^{-3}\right)$ & 41 & $1.25 \mathrm{E}-02$ & $6.61 \mathrm{E}+00$ & $2.51 \mathrm{E}+00$ & $2.61 \mathrm{E}+00$ & $1.83 \mathrm{E}+00$ \\
\hline Cs $\left(\mathrm{ng} \mathrm{m}^{-3}\right)$ & 28 & $6.03 \mathrm{E}-03$ & $1.81 \mathrm{E}-01$ & $2.98 \mathrm{E}-02$ & $4.21 \mathrm{E}-02$ & $4.23 \mathrm{E}-02$ \\
\hline $\mathrm{Fe}\left(\mathrm{ng} \mathrm{m}^{-3}\right)$ & 61 & $1.87 \mathrm{E}-02$ & $2.72 \mathrm{E}+02$ & $3.00 \mathrm{E}+01$ & $5.29 \mathrm{E}+01$ & $6.19 \mathrm{E}+01$ \\
\hline $\mathrm{Ge}\left(\mathrm{ng} \mathrm{m}^{-3}\right)$ & 24 & $6.41 \mathrm{E}+00$ & $4.62 \mathrm{E}+02$ & $5.47 \mathrm{E}+01$ & $9.20 \mathrm{E}+01$ & $1.13 \mathrm{E}+02$ \\
\hline $\mathrm{K}\left(\mathrm{ng} \mathrm{m}^{-3}\right)$ & 64 & $1.01 \mathrm{E}+02$ & $1.15 \mathrm{E}+03$ & $2.48 \mathrm{E}+02$ & $2.98 \mathrm{E}+02$ & $1.79 \mathrm{E}+02$ \\
\hline $\mathrm{Na}\left(\mathrm{ng} \mathrm{m}^{-3}\right)$ & 67 & $1.13 \mathrm{E}+01$ & $3.59 \mathrm{E}+03$ & $8.10 \mathrm{E}+02$ & $1.04 \mathrm{E}+03$ & $9.43 \mathrm{E}+02$ \\
\hline $\mathrm{Rb}\left(\mathrm{ng} \mathrm{m}^{-3}\right)$ & 46 & $1.05 \mathrm{E}-01$ & $7.29 \mathrm{E}+00$ & $8.81 \mathrm{E}-01$ & $1.33 \mathrm{E}+00$ & $1.25 \mathrm{E}+00$ \\
\hline $\mathrm{Sb}\left(\mathrm{ng} \mathrm{m}^{-3}\right)$ & 74 & $3.75 \mathrm{E}-03$ & $1.92 \mathrm{E}+00$ & $1.70 \mathrm{E}-01$ & $2.27 \mathrm{E}-01$ & $2.57 \mathrm{E}-01$ \\
\hline $\mathrm{Sc}\left(\mathrm{ng} \mathrm{m}^{-3}\right)$ & 24 & $1.15 \mathrm{E}-03$ & $1.07 \mathrm{E}-01$ & $1.11 \mathrm{E}-02$ & $2.51 \mathrm{E}-02$ & $3.00 \mathrm{E}-02$ \\
\hline $\mathrm{Se}\left(\mathrm{ng} \mathrm{m}^{-3}\right)$ & 44 & $1.21 \mathrm{E}-01$ & $1.18 \mathrm{E}+00$ & $3.03 \mathrm{E}-01$ & $3.40 \mathrm{E}-01$ & $2.12 \mathrm{E}-01$ \\
\hline $\operatorname{Sm}\left(\mathrm{ng} \mathrm{m}^{-3}\right)$ & 27 & $2.32 \mathrm{E}-05$ & $1.01 \mathrm{E}-01$ & $5.59 \mathrm{E}-03$ & $1.31 \mathrm{E}-02$ & $2.18 \mathrm{E}-02$ \\
\hline $\operatorname{Th}\left(\mathrm{ng} \mathrm{m}^{-3}\right)$ & 27 & $8.92 \mathrm{E}-03$ & $1.18 \mathrm{E}-01$ & $1.84 \mathrm{E}-02$ & $3.32 \mathrm{E}-02$ & $2.97 \mathrm{E}-02$ \\
\hline $\mathrm{W}\left(\mathrm{ng} \mathrm{m}^{-3}\right)$ & 33 & $3.18 \mathrm{E}-03$ & $1.52 \mathrm{E}-01$ & $3.01 \mathrm{E}-02$ & $3.94 \mathrm{E}-02$ & $3.45 \mathrm{E}-02$ \\
\hline $\mathrm{Yb}\left(\mathrm{ng} \mathrm{m}^{-3}\right)$ & 38 & $4.27 \mathrm{E}-03$ & $7.31 \mathrm{E}-02$ & $1.16 \mathrm{E}-02$ & $1.41 \mathrm{E}-02$ & $1.15 \mathrm{E}-02$ \\
\hline $\mathrm{Zn}\left(\mathrm{ng} \mathrm{m}^{-3}\right)$ & 68 & $2.05 \mathrm{E}-01$ & $5.31 \mathrm{E}+01$ & $7.21 \mathrm{E}+00$ & $8.50 \mathrm{E}+00$ & $7.41 \mathrm{E}+00$ \\
\hline $\mathrm{Cl}^{-}\left(\mathrm{ng} \mathrm{m}^{-3}\right)$ & 74 & $1.45 \mathrm{E}+01$ & $7.06 \mathrm{E}+03$ & $8.07 \mathrm{E}+02$ & $1.86 \mathrm{E}+03$ & $2.08 \mathrm{E}+03$ \\
\hline $\mathrm{NO}_{3}^{-}\left(\mathrm{ng} \mathrm{m}^{-3}\right)$ & 74 & $4.72 \mathrm{E}+01$ & $3.33 \mathrm{E}+03$ & $7.63 \mathrm{E}+02$ & $8.29 \mathrm{E}+02$ & $5.03 \mathrm{E}+02$ \\
\hline $\mathrm{SO}_{4}{ }^{2-}\left(\mathrm{ng} \mathrm{m}^{-3}\right)$ & 75 & $1.04 \mathrm{E}+01$ & $5.48 \mathrm{E}+03$ & $6.59 \mathrm{E}+02$ & $7.92 \mathrm{E}+02$ & $7.11 \mathrm{E}+02$ \\
\hline $\mathrm{Na}^{+}\left(\mathrm{ng} \mathrm{m}^{-3}\right)$ & 75 & $1.90 \mathrm{E}+00$ & $4.09 \mathrm{E}+03$ & $7.64 \mathrm{E}+02$ & $1.07 \mathrm{E}+03$ & $1.07 \mathrm{E}+03$ \\
\hline $\mathrm{NH}_{4}^{+}\left(\mathrm{ng} \mathrm{m}^{-3}\right)$ & 74 & $4.53 \mathrm{E}+00$ & $1.33 \mathrm{E}+03$ & $2.47 \mathrm{E}+02$ & $3.29 \mathrm{E}+02$ & $2.60 \mathrm{E}+02$ \\
\hline $\mathrm{K}^{+}\left(\mathrm{ng} \mathrm{m}^{-3}\right)$ & 77 & $5.94 \mathrm{E}+01$ & $5.81 \mathrm{E}+02$ & $1.93 \mathrm{E}+02$ & $2.16 \mathrm{E}+02$ & $1.01 \mathrm{E}+02$ \\
\hline $\mathrm{Mg}^{2+}\left(\mathrm{ng} \mathrm{m}^{-3}\right)$ & 75 & $2.67 \mathrm{E}+00$ & $4.66 \mathrm{E}+02$ & $9.08 \mathrm{E}+01$ & $1.24 \mathrm{E}+02$ & $1.19 \mathrm{E}+02$ \\
\hline $\mathrm{Ca}^{2+}\left(\mathrm{ng} \mathrm{m}^{-3}\right)$ & 69 & $1.93 \mathrm{E}+00$ & $2.26 \mathrm{E}+02$ & $8.14 \mathrm{E}+01$ & $8.28 \mathrm{E}+01$ & $5.43 \mathrm{E}+01$ \\
\hline $\mathrm{PM}_{10}\left(\mu \mathrm{g} \mathrm{m}^{-3}\right)$ & 77 & $5.69 \mathrm{E}+00$ & $68.3 \mathrm{E}+00$ & $19.8 \mathrm{E}+00$ & $22.0 \mathrm{E}+00$ & $10.4 \mathrm{E}+00$ \\
\hline Temperature $\left({ }^{\circ} \mathrm{C}\right)$ & 77 & $2.80 \mathrm{E}+00$ & $1.61 \mathrm{E}+01$ & $1.00 \mathrm{E}+01$ & $9.77 \mathrm{E}+00$ & $3.02 \mathrm{E}+01$ \\
\hline Humidity (\%) & 77 & $3.50 \mathrm{E}+01$ & $8.56 \mathrm{E}+01$ & $7.11 \mathrm{E}+01$ & $6.80 \mathrm{E}+01$ & $1.95 \mathrm{E}+01$ \\
\hline
\end{tabular}

$S D$ standard deviation

For INAA analysis, each half filter was rolled up, put into an aluminum foil and irradiated for $5 \mathrm{~h}$ at a thermal neutron flux of $2.4 \times 10^{12}-1.2 \times 10^{13} \mathrm{~cm}^{-2} \mathrm{~s}^{-1}$ in the Portuguese Research Reactor (RPI-ITN; nominal power $1 \mathrm{MW}$ ). After irradiation, the sample was removed from the foil and placed in a polyethylene container for measurement of gamma spectra. Samples were measured for $7 \mathrm{~h}$ after 3-5 days and $3-4$ weeks after irradiation with a liquid- $\mathrm{N}_{2}$ cooled ORTEC ${ }^{\circledR}$ coaxial hyperpure germanium detector $(1.90 \mathrm{keV}$ resolution at $1.33 \mathrm{MeV} ; 30 \%$ relative efficiency) and using an ORTEC $^{\circledR}$ automatic sample changer. The $\mathrm{k}_{0}$-INAA method [3] was used and $0.1 \% \mathrm{Au}-\mathrm{Al}$ alloy discs (with a thickness of $125 \mu \mathrm{m}$ and a diameter of $0.5 \mathrm{~cm}$ ) were used as comparators and irradiated concurrently with the samples. Blank filters were processed in the same way as the loaded filters. Quality control (QC) was implemented through the analysis of NISTSRM_1633a 'Coal Fly Ash', which was co-irradiated with the samples. A total of 10 replicates of the $\mathrm{QC}$ material were measured weighing $20-30 \mathrm{mg}$ each, with counting times of $1 \mathrm{~h}$ after 3-5 days and 3-4 weeks of decay.

Details of analytical determinations of water-soluble cations and anions by ion-exchange chromatography at the University of Aveiro were previously given [4].

Environmental data

$\mathrm{PM}_{10}$ values from Chamusca air quality station $\left(39^{\circ} 12^{\prime} 41^{\prime \prime} \mathrm{N}, 08^{\circ} 16^{\prime} 55^{\prime \prime} \mathrm{W}\right)$, which is a component of the 


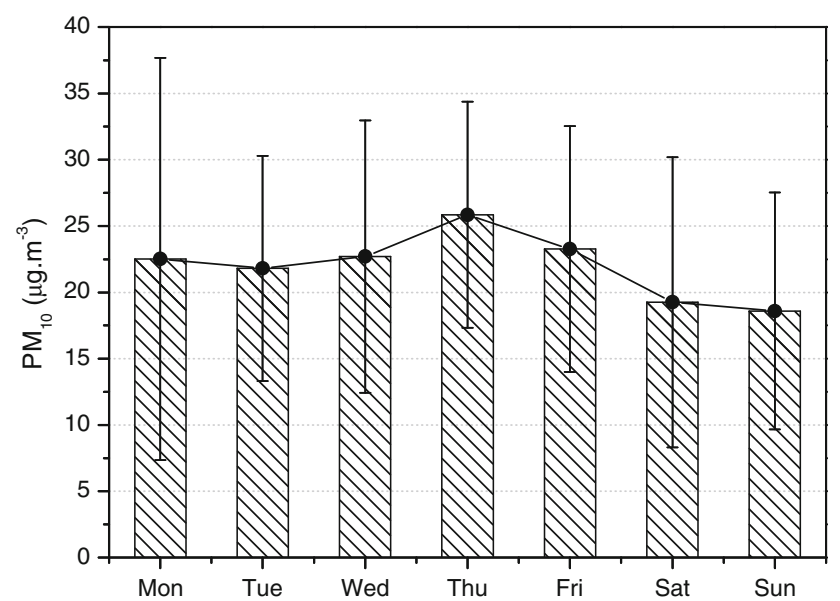

Fig. 3 Average daily concentrations of $\mathrm{PM}_{10}$ obtained by Partisol sampler during the sampling period (14 December 2009-6 March 2010)

Portuguese net of air quality monitoring stations named QualAr, were obtained from the online database of the Portuguese Environment Agency (APA) [5]. This station is $5.19 \mathrm{~km}$ from the sampling site and is considered as a station of regional rural environment and a background type.

\section{Statistical treatment}

Source apportionment was determined by Principal component factor analysis (PCA) [6] using STATISTICA software. The orthogonal transformation method with Varimax rotation was used and principal components retention was done to those which were greater than 1 . A selection of elements and ionic species was used to perform the factor analysis: $\mathrm{Sc}, \mathrm{Cr}, \mathrm{Fe}, \mathrm{Co}, \mathrm{Zn}, \mathrm{As}, \mathrm{Se}, \mathrm{Br}, \mathrm{Sb}, \mathrm{Cl}^{-}$, $\mathrm{NO}_{3}{ }^{-}, \mathrm{SO}_{4}{ }^{2-}, \mathrm{Na}^{+}, \mathrm{NH}_{4}{ }^{+}, \mathrm{K}^{+}, \mathrm{Mg}^{2+}, \mathrm{Ca}^{2+}$ and insoluble $\mathrm{K}$. Missing values were replaced with the series average of the particular parameter. The correlation of pollutant

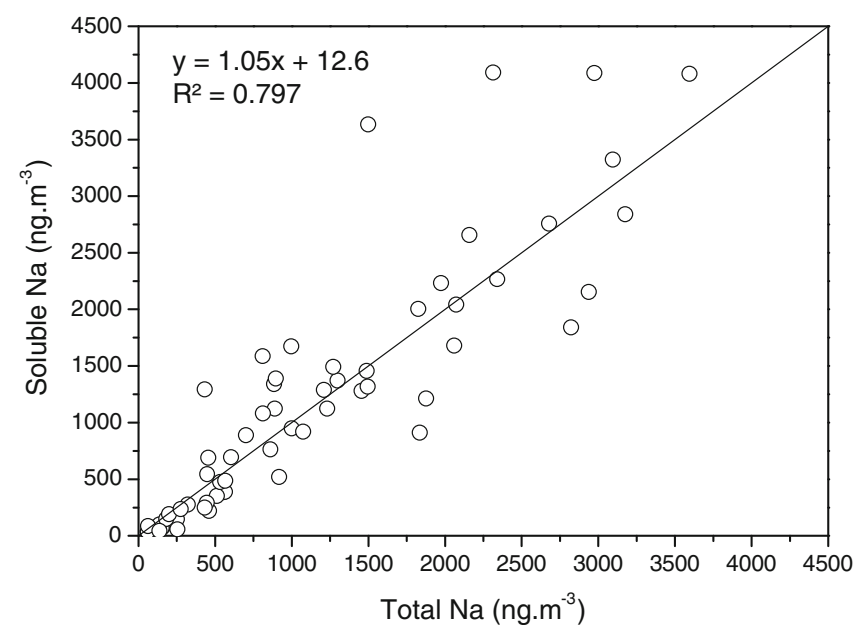

Fig. 4 Correlations between ionic and total $\mathrm{Na}$ and $\mathrm{K}$ species with each component is indicated by the factor loadings, which are related to the source emission composition.

\section{Results and discussion}

Figure 2 shows the results obtained by INAA for the reference material NIST-SRM_1633a 'Coal Fly Ash', with uncertainties at $95 \%$ confidence level. Overall, the ratio data is acceptable and only $\mathrm{Sb}$ presents an average value below the expected value. However, the $u$-score [7] for this element is 0.12 which means that the results do not differ significantly from the certified ones.

Table 1 shows the basic statistics on the chemical elements and water-soluble ions content of the collected $\mathrm{PM}_{10}$. The largest variances can be observed for soil elements $(\mathrm{Fe}, \mathrm{Sc}, \mathrm{Ge}, \mathrm{Co}, \mathrm{Sm})$ and for $\mathrm{Au}$ as well. Major elements (above $100 \mathrm{ng} \mathrm{m}^{-3}$ ) were $\mathrm{Ca}$, $\mathrm{Na}$ and $\mathrm{K}$ (total concentrations obtained by INAA) and the water-soluble ions (except for calcium cation). Calcium was the dominant metal element in the $\mathrm{PM}_{10}$ particles within a mass fraction range of $0.8-38.6 \%$.

The average mass concentration of $\mathrm{PM}_{10}$ was $22 \mu \mathrm{g} \mathrm{m}^{-3}$ (with a standard deviation of $47 \%$ and a variability within the range $5.69-68.3 \mu \mathrm{g} \mathrm{m}^{-3}$ ). This average value is below the annual limit value of $40 \mu \mathrm{g} \mathrm{m}^{-3}$ allowed by the EU (Directive 2008/50/EC). Daily concentrations of $\mathrm{PM}_{10}$ only were above the daily limit of $50 \mu \mathrm{g} \mathrm{m}^{-3}$ once in 77 days of sampling.

The averages of the daily concentrations of $\mathrm{PM}_{10}$ are shown in Fig. 3. Although a higher standard deviation is associated with the average $\mathrm{PM}_{10}$ concentrations, it is possible to observe a trend in which $\mathrm{PM}_{10}$ concentrations are lower at weekend than at weekdays. In fact, the average $\mathrm{PM}_{10}$ concentration at weekends was $18.9( \pm 0.5) \mu \mathrm{g} \mathrm{m}^{-3}$,

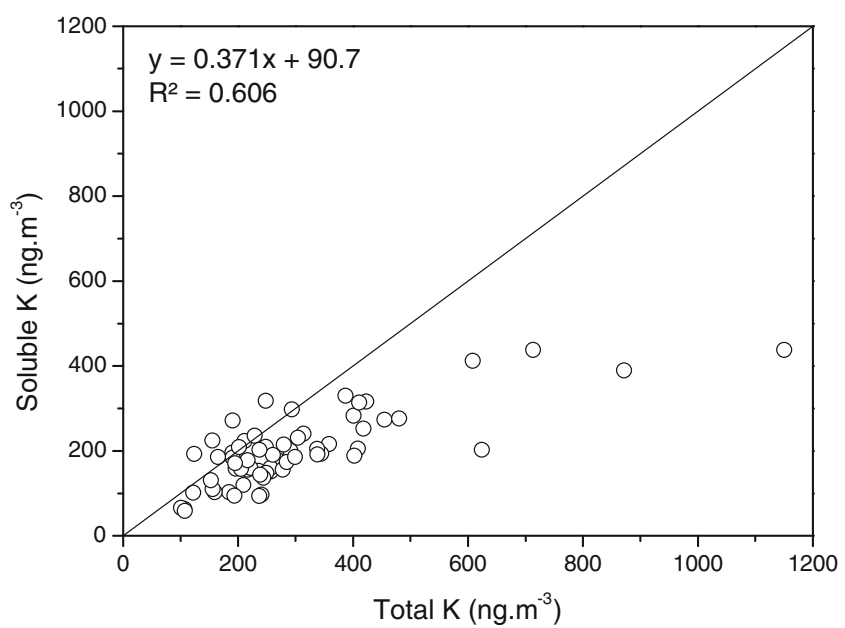


Table 2 Factors loading contributions to total element occurrence (most significant elements/ions by factor in bold and elements/ions with loadings above 0.45 ) obtained by PCA

\begin{tabular}{lllllll}
\hline Element/ion & Factor 1 & Factor 2 & Factor 3 & Factor 4 & Factor 5 & Factor 6 \\
\hline $\mathrm{As}$ & & & & & & \\
$\mathrm{Br}$ & 0.64 & & & & 0.60 & \\
$\mathrm{Co}$ & & & & & \\
$\mathrm{Cr}$ & & $\mathbf{0 . 7 5}$ & & $\mathbf{0 . 8 3}$ \\
$\mathrm{Fe}$ & & & & & \\
$\mathrm{Sb}$ & & $\mathbf{0 . 8 4}$ & & & & \\
$\mathrm{Sc}$ & & & & $\mathbf{0 . 9 0}$ & $\mathbf{0 . 8 3}$ & \\
$\mathrm{Se}$ & & & & $\mathbf{0 . 8 9}$ & & \\
$\mathrm{Zn}^{-}$ & $\mathbf{0 . 9 2}$ & & & & & \\
$\mathrm{Cl}^{-}$ & & & $\mathbf{0 . 7 5}$ & & & \\
$\mathrm{NO}_{3}{ }^{-}$ & & & 0.57 & & \\
$\mathrm{SO}_{4}{ }^{2-}$ & $\mathbf{0 . 9 2}$ & & & & \\
$\mathrm{Na}^{+}$ & & & $\mathbf{0 . 7 1}$ & & \\
$\mathrm{NH}_{4}{ }^{+}$ & & & 0.56 & & \\
$\mathrm{~K}^{+}$ & & & & & \\
$\mathrm{Mg}^{2+}$ & $\mathbf{0 . 9 5}$ & 0.45 & & & \\
$\mathrm{Ca}^{2+}$ & & $\mathbf{0 . 9 0}$ & & & \\
$\mathrm{K} \mathrm{non} \mathrm{soluble}$ & & & & & \\
\hline
\end{tabular}

while at weekdays the average value was 23.2 $( \pm 1.6) \mu \mathrm{g} \mathrm{m}^{-3}$. This fact means that during weekdays there is a local source of $\mathrm{PM}_{10}$ that does not exist in weekends. Due to the location of the sampler, it is reasonable to suggest that the additional source of $\mathrm{PM}_{10}$ during weekdays is the smoke from burning wood in the primary school.

The average ratio between $\mathrm{PM}_{10}$ concentrations obtained by the QualAr station and the Partisol sampler for the same sampling period was of $0.54( \pm 0.26)$. The weekdays and weekends average values of $\mathrm{PM}_{10}$ concentrations obtained by the QualAr station were $10.5 \pm 2.3$ and $11.0 \pm 0.1 \mu \mathrm{g} \mathrm{m}^{-3}$, respectively. These results confirm the QualAr station is a good choice to use as a baseline for a non-contaminated area and it is possible to conclude that the high $\mathrm{PM}_{10}$ concentrations obtained at the sampling site are due to local sources.

Figure 4 shows the correlations between the total and ionic concentrations of $\mathrm{K}$ and $\mathrm{Na}$. The correlation coefficients were 0.606 and 0.797 for $\mathrm{K}$ and $\mathrm{Na}$, respectively. For $\mathrm{Na}$, the concentrations values of the total and ionic forms of the element are similar with a few exceptions. However, for $\mathrm{K}$ it is possible to observe a trend were the concentration of total form is higher than the soluble form. This fact suggests that a component of $\mathrm{K}$ is not being considered (insoluble form). Therefore, since concentrations of total and ionic forms were obtained for this element, the insoluble potassium concentration was obtained by subtracting the soluble fraction concentration from the total concentration of the element. In fact, the use of independent methods, as INAA and ion-exchange chromatography, can give information about elemental solubility, which can subsequently be used to differentiate sources associated with the soluble and insoluble fractions [8].

The results of the PCA analysis of the considered data are shown on Table 2 and a total of six main chemical source profiles were identified.

Factor 1 presented high factor loadings (above 0.64) for the element $\mathrm{Br}$ and the ions $\mathrm{Cl}^{-}, \mathrm{Na}^{+}$and $\mathrm{Mg}^{2+}$. Their significant values suggest the consideration of this factor as the marine contribution, due to its typical composition [8].

For factor 2, Sc, Fe and insoluble $\mathrm{K}$ were the elements with higher factor loadings (above 0.75 ) along with soluble $\mathrm{Ca}(0.45)$. These elements are typical from a soil source and, therefore, this factor represents the soil contribution.

Factor 3 is identified as secondary aerosols since its contributions are mainly from $\mathrm{SO}_{4}{ }^{2-}, \mathrm{NH}_{4}{ }^{+}, \mathrm{NO}_{3}{ }^{-}$and $\mathrm{K}^{+}$. Soluble $\mathrm{K}$ is also known to be one of the main components of the wood ash [9] and, therefore, we suggest that in this situation the source of this cation is wood burning.

The elements with the highest loadings given by factor 4 were $\mathrm{Sb}$ and $\mathrm{Zn}$ (0.90 and 0.88 , respectively). These elements are usually associated with coal combustion, incineration and traffic (mainly tires and brake wear) [10]. Due to the existence of a coal power plant nearby $(34.16 \mathrm{~km}$ away from the sampling site), it is suggested that this factor is derived from coal combustion, along with some contribution from traffic. 
Factor 5 correlated with Se and this element presented an anti-correlation with Co. Selenium may indicate industry and combustion sources.

Factor 6 presented higher factor loadings for $\mathrm{Cr}(0.83)$ which is often related to industrial sources.

\section{Conclusions}

This study confirmed the contribution of the smoke from wood burning to the $\mathrm{PM}_{10}$ concentrations on the ambient air in a small village where this kind of heating is used in the colder months. The analysis of the daily variability of the $\mathrm{PM}_{10}$ concentrations indicated a local source on weekdays which contributed to an increase in the $\mathrm{PM}_{10}$ concentrations in air. A chemical profile of the $\mathrm{PM}_{10}$ particles was determined with main components of watersoluble ions and total $\mathrm{Ca}$.

The combined use of the two analytical techniques (INAA and ion-exchange chromatography) provided information about elemental solubility, which was important to differentiate sources associated to the soluble and insoluble fractions. In fact, soluble potassium was revealed to be associated with the secondary aerosols. Since this chemical specie is also known to be one of the main components of the biomass ash, our results conclude the existence of a contribution from the burn wood smoke to the $\mathrm{PM}_{10}$ emissions in the studied rural site.
Acknowledgments Financial support by Fundação para a Ciência e a Tecnologia (FCT; Portugal) through research contract PTDC/SAUESA/65597/2006 is gratefully acknowledged. N. Canha thanks FCT for his $\mathrm{PhD}$ grant.

\section{References}

1. Borrego C, Valente J, Carvalho A, Sá E, Lopes M, Miranda AI (2010) Atmos Environ 44:642-651

2. Gonçalves C, Alves C, Evtyugina M, Mirante F, Pio CA, Caseiro A, Schmidl C, Bauer H, Carvalho F (2010) Atmos Environ 44:4474-4480

3. Corte F (1987) Agregé Thesis, Gent University, Belgium

4. Almeida SM, Farinha MM, Ventura MG, Pio CA, Freitas MC, Reis MA, Trancoso MA (2007) Water Air Soil Pollut 179:43-55

5. QualAr, APA (2011) http://www.qualar.org. Accessed 9 Mar 2011

6. Almeida SM, Pio CA, Freitas MC, Reis MA, Trancoso MA (2006) Sci Total Environ 368:663-674

7. Dung HM, Freitas MC, Blaauw M, Almeida SM, Dionísio I, Canha NH (2010) Nucl Instrum Methods Phys Res A 622:392-398

8. Almeida SM, Freitas MC, Reis MA, Pio CA, Trancoso MA (2006) Nucl Instrum Methods Phys Res A 564:752-760

9. Schmidl C, Marr IL, Caseiro A, Kotianová P, Berner A, Bauer H, Kasper-Giebl A, Puxbaum H (2008) Atmos Environ 42:126-141

10. Almeida SM, Pio CA, Freitas MC, Reis MA, Trancoso MA (2005) Atmos Environ 39:3127-3138

11. Roelandts I, Gladney ES (1998) Fresenius J Anal Chem 360: 327-338 